\title{
SUNFLOWER YIELD AND CLIMATIC VARIABLES
}

González, J.*, Mancuso, N., Ludueña, P.

National Institute of Agricultural Technology (INTA), Pergamino Agricultural Experimental Station, C.C.31 (2700) Pergamino, Buenos Aires Argentina

Received: December 20, 2012 Accepted: June 10, 2013

\section{SUMMARY}

A group of hybrids with higher oil yield was selected from the comparative yield trials carried out in the EEA Pergamino, during seasons 2004-2005, 2005-2006 and 2006-07. The objective was to study the associations between seed yield, oil content, oil yield and climatic variables obtained from two methods: stepwise and principal component analysis. Both methods arrived at similar results confirming the associations between yield and climatic variables. Positive correlation between seed yield and thermal amplitude was obtained in sowing- flowering, as well as between oil yield and thermal amplitude in flowering- maturity. The seed yield was negatively correlated with the hours of sunlight (heliophany) and rainfall in sowing-flowering. The oil content was positively correlated with the hours of sunlight (heliophany) in flowering- maturity and with thermal amplitude in flowering maturity. As the variations of climatic variables have a substantial importance in determining yield, the selection of stable genotypes would be an important contribution to sunflower breeding.

Key words: sunflower, climatic variables, multivariate analysis, stepwise, yield

\section{INTRODUCTION}

A hybrid yield is conditioned by its capacity to use efficiently the environmental variables in different phenophases.

The climatic variables contribute in an important way to the definition of the environment, this is the reason why the knowledge of the correlations between the climatic variables and yield could explain the results obtained in different years.

Seiler (1983) informed that temperature, total solar energy and day length influenced the content and quality of sunflower oil.

Magrin et al. (1998) reported that in the "niña" years (rainfall below to average in season June to December) there existed the probability to obtain high yield in

* Corresponding autor: Phone: +54247743902; e-mail: pergira@pergamino.inta.gov.ar 
sunflower. Chimenti et al. (2001) informed that constant air temperatures above $25^{\circ} \mathrm{C}$ during the whole period of grain filling decreased the final weight of grains.

De la Vega and Chapman (2000) found negative correlation between yield and rainfall from blooming to flowering time, while Anastasi et al. (2004) showed that the climatic conditions during the period of grain filling and maturity influenced sunflower yield.

Rondanini et al. (2003) concluded that the application of constant grain temperatures above $34^{\circ} \mathrm{C}$ in different periods of grain filling for seven consecutive days, reduced the oil weight and content, being the early subphases the most sensitive to stress.

Andrade et al. (2005) concluded that a period bracketing flowering has been found to be most critical for seed number and yield in sunflower.

Fernandez-Moya et al. (2005) stated that long periods of high temperature during grain filling resulted in low oil content and poor seed quality.

The study of associations among variables is done with different methods; one of them is the path coefficient (Wright, 1921), method from which "stepwise" developed.

This method allows the identification of possible explanations about the causes of the correlations observed between a variable response and a series of predictive variables.

Another method used is the analysis of the principal components represented in the biplot graphics. The observations and variables that make the interpretation possible are shown in a graphic with the analysis of the interdependence of metric variables and the best representation of data.

Both methods are considered to contribute in a different way and they also complement each other. The stepwise method analyses shows the predictive contribution of the different variables. The method of principal components developed through a multivariate analysis and a graphic representation in a biplot allows the visual appreciation of correlations between variables.

The objectives were to analyze the association between seed yield, percentage of oil content, oil yield and climatic variables obtained from two methods and to compare the results.

\section{MATERIALS AND METHODS}

Analyzed data was obtained from sunflower experiences in trials conducted at EEA Pergamino INTA (33 $57^{\prime} \mathrm{S}, 6^{\circ} 34^{\prime} \mathrm{W}$ ), Argentina. Data included information from 2004/05, 2005/06 and 2006/07. The site is located in the north of the humid pampas, on an Argiudol soil (typical of Pergamino). Climate is temperate, with an average annual rainfall of $973 \mathrm{~mm}$. The statistical design of the trials was randomized complete block with 3 replications and plots of 3 rows of $6.0 \mathrm{~m}$, row spacing of $0.7 \mathrm{~m}$. The hybrids CF 29, DK3820, Paraíso 22 and SPS 3105 that did not have significant differences with the highest oil yield per hectare in at least two of the three seasons were analyzed. 
Trials were conducted rainfed with conventional tillage. Fertilizers and agrochemical products were used depending on each particular case. Trials were planted according recommended period for that region.

The attributes analyzed were: plant height $(\mathrm{cm})$, grain yield $\left(\mathrm{kg} \mathrm{ha}^{-1}\right)$, oil concentration (\%) and oil yield ( $\left.\mathrm{kg} \mathrm{ha}^{-1}\right)$. Grain yield (11\% moisture) was obtained from the harvest of the central row of each plot, removing the first and last plant (3.99 $\mathrm{m}^{2}$ ). Oil concentration was determined by nuclear magnetic resonance (Granlund and Zimmerman, 1975). Oil yield was obtained from grain yield and oil concentration. The physiological maturity was estimated by the change in color of the tips of the bracts yellowish green to brown, at that time the receptacle has an intense yellow color.

Table 1: Climatic variables of two phenologic stages sowing-flowering and flowering-maturity of four sunflower hybrids

\begin{tabular}{lccccccc}
\hline Genotype & Year & PAS & PSF & TMSF & TMiSF & ASF & HSF \\
\hline DK 3820 & $2004 / 05$ & 61 & 242.3 & 28.45 & 15.15 & 13.3 & 7.3 \\
PARAISO 22 & $2004 / 05$ & 61 & 240.7 & 28.5 & 15.18 & 13.33 & 7.35 \\
CF 29 & $2005 / 06$ & 59.9 & 214.1 & 29.57 & 15.77 & 13.8 & 7.5 \\
PARAíSO 22 & $2005 / 06$ & 59.9 & 163.9 & 30 & 15.73 & 14.27 & 7.8 \\
SPS 3105 & $2005 / 06$ & 59.9 & 173.5 & 29.77 & 16.87 & 12.9 & 7.7 \\
CF 29 & $2006 / 07$ & 136 & 334.6 & 28.6 & 15.57 & 13.03 & 8.47 \\
DK 3820 & $2006 / 07$ & 136 & 334.6 & 28.5 & 15.6 & 12.9 & 9.07 \\
PARAISO 22 & $2006 / 07$ & 136 & 334.6 & 28.5 & 15.57 & 12.93 & 8.37 \\
SPS 3105 & $2006 / 07$ & 136 & 334.6 & 28.5 & 15.6 & 12.9 & 8.4 \\
\hline Genotype & Year & & PFM & TMFM & TMiFM & AFM & HFM \\
\hline DK 3820 & $2004 / 05$ & & 165.6 & 28.35 & 14.85 & 13.5 & 8.8 \\
PARAISO 22 & $2004 / 05$ & & 165.6 & 28.2 & 14.85 & 13.35 & 8.75 \\
CF 29 & $2005 / 06$ & & 185 & 27.43 & 14.77 & 12.67 & 7.03 \\
PARAÍSO 22 & $2005 / 06$ & & 140.9 & 29.35 & 16.55 & 12.8 & 7.2 \\
SPS 3105 & $2005 / 06$ & & 196.2 & 29.05 & 16.35 & 12.7 & 6.85 \\
CF 29 & $2006 / 07$ & & 347.6 & 27.1 & 14.8 & 12.3 & 7.57 \\
DK 3820 & $2006 / 07$ & & 276.6 & 27.4 & 14.8 & 12.6 & 7.43 \\
PARAISO 22 & $2006 / 07$ & & 276.6 & 27.4 & 14.7 & 12.7 & 7.5 \\
SPS 3105 & $2006 / 07$ & & 347.6 & 27.233 & 14.6 & 12.633 & 7.67 \\
\hline REFERENCES: & & & & & & &
\end{tabular}

REFERENCES:

PAS: rainfall of the month prior to sowing $(\mathrm{mm}), \mathrm{PSF}$ : rainfall from sowing to flowering $(\mathrm{mm})$, TMSF: maximum temperature from sowing to flowering $\left({ }^{\circ} \mathrm{C}\right)$, TMiSF minimum temperature from sowing to flowering $\left({ }^{\circ} \mathrm{C}\right)$, ASF: temperature range from sowing to flowering $\left({ }^{\circ} \mathrm{C}\right)$, HSF: heliophany from sowing to flowering (hs), PFM: rainfall from flowering to maturity $(\mathrm{mm})$,TMFM: maximum temperature from flowering to maturity $\left({ }^{\circ} \mathrm{C}\right) \mathrm{TMiFM}$ minimum temperature from flowering to maturity $\left({ }^{\circ} \mathrm{C}\right)$, AFM: temperature range from flowering to maturity $\left({ }^{\circ} \mathrm{C}\right)$, HFM: heliophany from flowering to maturity (hs)

The climatic variables analyzed were PAS: rainfall of the month prior to sowing $(\mathrm{mm})$, PSF: rainfall from sowing to flowering (mm), TMSF: maximum temperature 
from sowing to flowering $\left({ }^{\circ} \mathrm{C}\right)$, TMiSF minimum temperature from sowing to flowering $\left({ }^{\circ} \mathrm{C}\right)$, ASF: temperature range from sowing to flowering $\left({ }^{\circ} \mathrm{C}\right)$, HSF: heliophany from sowing to flowering (hs), PFM: rainfall from flowering to maturity (mm), MFT: maximum temperature from flowering to maturity $\left({ }^{\circ} \mathrm{C}\right) \mathrm{TMiFM}$ minimum temperature from flowering to maturity $\left({ }^{\circ} \mathrm{C}\right)$, AFM: temperature range from flowering to maturity $\left({ }^{\circ} \mathrm{C}\right)$, HFM: heliophany from flowering to maturity (hs).

The stepwise method and principal components analysis (regression analysis) were used to determine which variables associated significantly with seed yield, oil content and oil yield.

The principal components (PCs) of the squares of Euclideas distances were estimated using a procedure of singular value decomposition (Gabriel, 1971)

The standardization of variables was performed considering a mean equal to zero and an absolute mean deviation equal to one. The biplot of the two first PCs was completed with the results of this analysis.

\section{RESULTS AND DISCUSSION}

Paraíso 22 hybrid was short cycle in sowing-flowering and in flowering-maturity, and hybrids CF 29 and DK 3820 were long cycle to flowering (Table 2).

Table 2: Days of sowing- flowering and flowering-maturity phenophases of four sunflower hybrids during three seasons

\begin{tabular}{lcccccc}
\hline \multirow{2}{*}{ Genotype } & \multicolumn{2}{c}{$2004-05$} & \multicolumn{2}{c}{$2005-06$} & \multicolumn{2}{c}{$2006-07$} \\
\cline { 2 - 7 } & S-F & FM & S-F & FM & S-F & FM \\
\hline DK 3820 & 73 & 43 & s/d & s/d & 69 & 49 \\
PARAISO 22 & 72 & 40 & 69 & 41 & 67 & 51 \\
CF 29 & -- & -- & 73 & 48 & 70 & 51 \\
SPS 3105 & -- & -- & 70 & 44 & 69 & 52 \\
\hline REF
\end{tabular}

\section{REFERENCES:}

SF: days from sowing to flowering, FM: days from flowering to maturity

The 2004-05 season was the season with the most oil content and the widest thermal amplitude from flowering to maturity (Table 3).

Table 3: Height, yield, percentage of oil content averages and climatic variables in two phenophases during three seasons

\begin{tabular}{lccccccccc}
\hline Year & S-F & FM & ALT & RENS & OIL & RENA & PSF & HSF & AFM \\
\hline $2004-05$ & 72.5 & 41.5 & 170 & 3526 & 54.25 & 1911 & 241.5 & 7.33 & 13.43 \\
$2005-06$ & 70.7 & 44.3 & 140 & 3702 & 47.69 & 1765 & 183.8 & 7.67 & 12.72 \\
$2006-07$ & 68.8 & 50.8 & 166 & 3009 & 47.76 & 1440 & 334.6 & 8.57 & 12.56 \\
\hline
\end{tabular}

REFERENCES: SF: days from sowing to flowering, FM: days from flowering to maturity, ALT: plant height $(\mathrm{cm})$ RENS: seed yield $\left(\mathrm{kg} \mathrm{ha}^{-1}\right)$, OIL:oil percentage content, RENA: oil yield $\left(\mathrm{kg} \mathrm{ha}^{-1}\right)$; PSF rainfall from sowing to flowering $(\mathrm{mm})$, HSF: heliophany from sowing to flowering (hs), AFM:

temperature range from flowering to maturity $\left({ }^{\circ} \mathrm{C}\right)$ 
Table 4: Correlation between seed yield, oil yield and oil content with climatic variables by the stepwise method

\begin{tabular}{lcc}
\hline & Grain yield & R2: 0.86 \\
& & $P$ value \\
PSF(-) & & 0.0642 \\
HSF(-) & & 0.085 \\
\hline & Oil (\%) & R2: 0.74 \\
& & P value \\
AFM(+) & Oil yield & R2: 0.96 \\
\hline & & P value \\
$\operatorname{PSF}(-)$ & & 0.0724 \\
HSF $(-)$ & & 0.0515 \\
AFM(+) & & 0.0498 \\
\hline
\end{tabular}

\section{Stepwise method analysis}

The analysis of the described variables with the method stepwise (Table 4) had the following results. The seed yield was negatively correlated with rainfall and with heliophany in sowingflowering. The oil content was positively correlated with thermal amplitude in flowering-maturity. The oil yield was negatively correlated with rainfall and heliophany in sowing-flowering, and positively with thermal amplitude in flowering-maturity. No significant correlation was found among the other variables analyzed.

\section{Analysis of principal components}

The correlations between variables and seasons observed in the biplot indicate three differentiated environments: 2004-05, 2005-06 and 2006-07. The year component had a relevant incidence in the determination of yield and oil content. Consequently, the number of years for evaluation should be increased to adjust the hybrid performance with more precision.

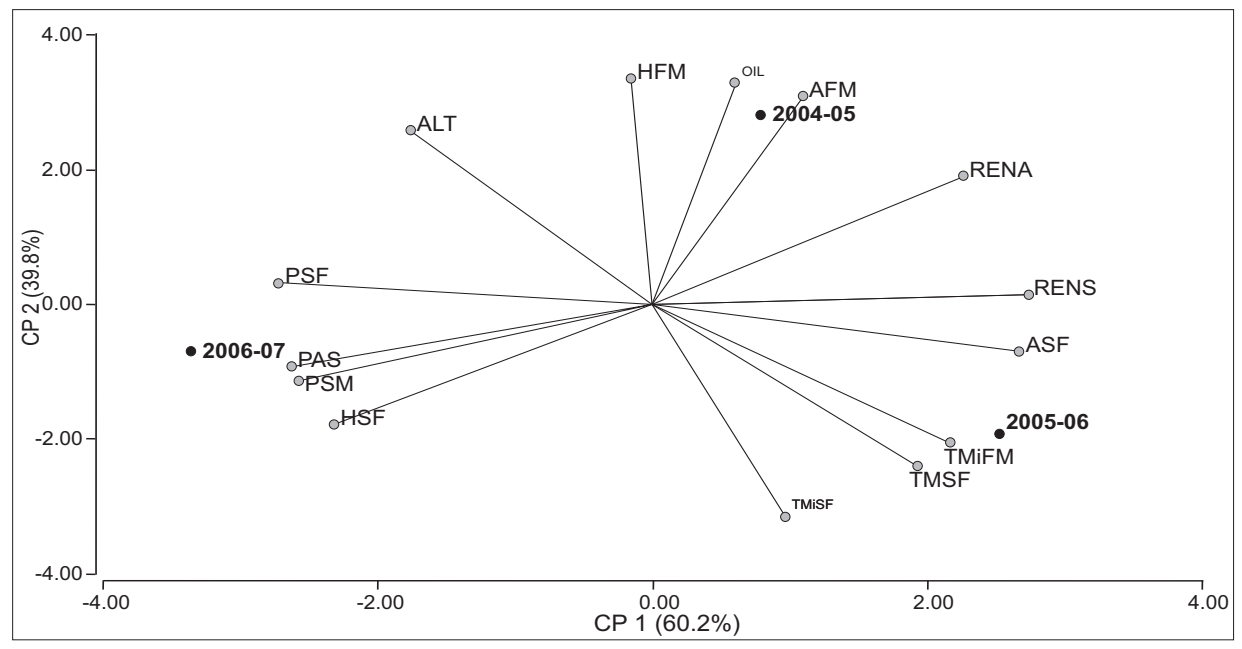

Figure 1: Correlation among yield, oil content and climatic variables in two phenophases.

In the analysis of the principal components, positive correlation was obtained between seed yield and thermal amplitude in phenopase flowering-maturity. The seed yield was negatively correlated with heliophany and rainfall in sowing- flower- 
ing; coinciding with the results of the stepwise analysis. The oil content was positively correlated with heliophany and with thermal amplitude in floweringmaturity; coinciding with the results obtained with the stepwise method.

In the analysis of the principal components, positive correlation was obtained between seed yield and thermal amplitude in phenopase flowering-maturity. The seed yield was negatively correlated with heliophany and rainfall in sowing- flowering; coinciding with the results of the stepwise analysis. The oil content was positively correlated with heliophany and with thermal amplitude in floweringmaturity; coinciding with the results obtained with the stepwise method.

The positive association between oil content and thermal amplitude coincided with Rondanini et al. (2003) who conclude that the application of constant temperatures in different periods of grain filling reduced the weight and the oil content, and with Fernandez-Moya et al. (2005) who informed about the low oil content in long periods of high temperatures.

The negative association between seed yield and rainfall in the phenophase sowing-flowering coincided with what was found de la Vega and Chapman (2000) who obtained negative correlation between yield and rainfall in blooming and flowering stages. This result was also related to what was informed by Magrin et al. (1998), who stated that rainfall superior to average reduced sunflower yield.

Both methods obtained similar results in the associations between yield and climatic variables. Therefore, thermal amplitude sowing-flowering (ASF) and flowering-maturity ( $\mathrm{AFM}$ ) would be the variables which could explain to a great extent the climatic variation of the environmental component involved in the determination of yield.

Taking into account that the hybrids analyzed reached the highest yield in the seasons studied, it can be inferred that such variables tend to maximize the potential yield. Besides the hybrids evaluated would be the hybrids that take advantage of the climatic conditions in different seasons.

As the variations of climatic variables have a substantial importance in determining yield, the selection of stable genotypes would be an important contribution to sunflower breeding.

\section{ACKNOWLEDGEMENTS}

The authors are grateful to Catalina Amendola from the Statistics Group of the INTA Pergamino Agricultural Experimental Station for his invaluable assistance in the statistical analysis of this work. 


\title{
REFERENCES
}

Anastasi, U., Cammarata, M. and Abbate, V., 2002. Yield potential and oil quality of sunflower (oleic and standard) grown between autumn and summer. Ital. J. Agron. 4: 23-36.

Andrade, F.H., Sadras, V.O., Vega, C.R.C. and Echarte, L., 2005. Physiological determinants of crop growth and yield in maize, sunflower and soybean: their application to crop management, modeling and breeding. J. Crop Improv. 14: 51-101.

Balzarini, M., Di Rienzo, J.. 2004. Info-Gen: Software para análisis estadístico de datos genéticos. Universidad Nacional de Córdoba. Córdoba. Argentina.

Chimenti, C., Hall, A., López, M., 2001. Field Crops Res. 69: 81-88.

De La Vega, A.J., Chapman, S.C., 2000. Environmental attributes underlying environmental main effects and genotype environmental interactions in sunflower. In Proc. $15^{\text {th }}$. Int. Sunflower Conf. Toulouse France. pp D 112- D 116.

De La Vega, A.J., Hall, A.J., 2002. Effects of planting date, genotype, and their interactions on sunflower yield: I. Determinants of oil-corrected grain yield. Crop Sci. 42:1191-1201.

De La Vega, A.J. and Hall, A.J., 2002. Effect of planting date, genotype, and their interaction on sunflower yield. II. Components of oil yield. Crop. Sci. 42: 1202-1210.

Draper Norman R. Y Smith Harry. "Applied Regression Analysis”, Third Edition, John Wiley \& Sons., 1998.

Fernandez-Moya, V., Martinez-Force, E. and Garces, R., 2005. Oils from improved high stearic acid sunflower seeds. J. Agric. Food Chem. 53: 5326-5330.

Fox , P.N., Rosielle A.A., 1982. Reference sets of genotypes and selection for yield in unpredictable environments. Crop Sci. 22: 1171-1175.

Gabriel, K.R., 1971. The biplot graphic display of matrices with application to principal component análisis. Biometrika 58: 453-467.

Granlund, M., Zimmerman, D.C., 1975. Effect of drying conditions on oil content of sunflower (H. annuus L.) seeds as determined by wide-line nuclear magnetic resonance (NMR). North Dakota Acad. Sci. Proc. 27(2): 128-132.

Magrin, G.O., Grondona, M.O., Traverso M.I., Boullón D.R., Rodriguez G.R., Messina C.D., 1988. Impacto del Fenómeno "El Niño" sobre la Producción de Cultivos en la Región Pampeana .INTA .Instituto de Clima y Agua.Castelar.

Rondanini, D., Savin, R., Hall, A.J., 2003. Dynamics of fruit growth and oil quality of sunflower (Helianthus annuus L.) exposed to brief intervals of high temperature during grain filling. Field Crops Research 83: 79-90.

SAS Institute Inc., SAS/STAT Documentation, Version 9.2, Cary, NC: SAS Institute Inc., 2008.

Seiler, G.J., 1983. Effect of genotype, flowering date, and environment. Vol. 23, NovemberDecember, 1983, pp. 1063-1068

Szemruch, C., Introna, D., Guevara, E.R., Meira, S.. XIII Reunión Latinoamericana, XXVII Reunión Argentina de Fisiología Vegetal. Sociedad Argentina de Fisiología Vegetal. SAFV. Rosario, 21 al 24 de septiembre de 2008.

\section{RENDIMIENTO DE GIRASOL Y VARIABLES CLIMÁTICAS}

\author{
RESUMEN
}

De los ensayos comparativos de rendimiento conducidos en la EEA Pergamino durante las campañas 2004-05, 2005-06 y 2006-07, se tomó el grupo de híbridos superior que no se diferenciara por rendimiento de aceite. El objetivo fue estimar las asociaciones entre rendimiento de semilla, contenido porcentual de aceite, rendimiento de aceite y variables climáticas: precipitación, temperatura y heliofanía en las diferentes fenofases a partir de dos métodos: stepwise y componentes principales. Los dos métodos arrojaron resultados similares confirmando las asociaciones entre rendimiento y variables climáticas. Se obtuvo correlación positiva entre rendimiento de semilla y la amplitud térmica en siembra - floración y rendimiento de aceite y amplitud térmica en 
floración-madurez. El rendimiento de semilla se correlacionó negativamente con heliofanía y precipitaciones en siembra floración. El contenido porcentual de aceite se correlacionó positivamente con heliofanía en floración-madurez y con amplitud térmica en floración - madurez. Considerando la gran importancia de las variaciones interanuales de las variables climáticas en la determinación del rendimiento, la selección de genotipos estables sería un aporte importante del mejoramiento de girasol. 